\title{
Acquisitions, Multinationals, and Wage Dispersion
}

\author{
Fredrik Heyman** \\ Fredrik Sjöholm* \\ Patrik Gustavsson Tingvall*
}

\begin{abstract}
Multinational firms pay relatively high wages. Less is known about the wage structure within multinational and non-multinational firms. We examine the impact of acquisitions on wage dispersion in Sweden using a large matched employer-employee data set. Foreign acquisitions of Swedish firms increase wage dispersion by increasing wages for high-skilled workers. The positive impact is concentrated to CEOs and managers, whereas other groups are either negatively affected or not affected at all. The impact on high-skilled workers' wages seems to be caused by the acquisition rather than the ownership itself, since ownership changes from foreign to Swedish result in similar increases.
\end{abstract}

JEL: F23, J31, C23

Keywords: FDI, Multinational Companies, Foreign ownership, Wage-Dispersion, Skill groups, Matched Employer-Employee data.

Acknowledgements: We are grateful for comments and suggestions from Andrew Bernard, Gunnar Isaksson and Jarle Møen, conference participants at Nottingham, Stockholm, Shanghai, and seminar participants at Stockholm University. Patrik Gustavsson Tingvall gratefully acknowledges financial support from Jan Wallander's Research Foundation and the Swedish Council for Working Life and Social Research (FAS). Fredrik Heyman acknowledges financial support from the Swedish Council for Working Life and Social Research (FAS). 


\section{Introduction}

Increased integration of the global economy has changed relative incomes around the world. For instance, competition from imports of relatively low-skill intensive products has a downward pressure on wages for unskilled workers in wealthy nations and contributes to widening income disparities (e.g. Baldwin, 1994). Less attention has been given to the effect of Foreign Direct Investment (FDI) on income disparities. This is unfortunate since FDI has increased dramatically both in size and importance during the last decades, growing faster than international trade.

One aspect of FDI and wages which has received attention, is the relatively high wages in foreign-owned firms. It seems to be a universal rule that in every country, foreign-owned firms tend to pay higher average wages than domesticallyowned ones. ${ }^{1}$ However, more detailed analyses of individuals' wages find that part of this wage difference can be attributed to differences in worker characteristics, and that foreign-owned firms pay higher wages than local non-multinational firms, but not higher than local multinational firms (Heyman et al., 2004). Hence, it is not the nationality of the firm that is of importance for wages, but whether it is a multinational or a non-multinational firm, which is also what is to be expected from economic theory (see e.g. Markusen, 2004).

Although average wages do not seem to differ between local and foreignowned firms, there might be a difference in the wage structures. There are reasons to expect multinational firms in general, and perhaps foreign multinationals in particular, to pay comparably high wages for key employees. For instance, multinational firms might pay a wage premium to high-skilled workers to avoid labor turnover and the resulting loss of their firm-specific advantages. Furthermore, foreign

\footnotetext{
${ }^{1}$ See Görg and Greenaway (2004) and Lipsey (2004) for two surveys on FDI and wages.
} 
MNCs might import foreign wage structures to their affiliates; wage structures that might differ from wages in local firms.

There are few studies on the impact of foreign acquisitions on wage dispersion. In studies on average wage levels at an industry level, Taylor and Driffield (2005) find FDI to have a positive effect on wage dispersion in the UK, whereas Bloningen and Slaughter (1999) find no such effect in the US. There are also two studies touching upon the issue at a more disaggregated level. Girma and Görg (2003) use UK establishment data with the average wage of the workforce and find non-production workers to benefit from US acquisitions, whereas production workers only benefit in some industries. Thus, the results are suggesting that wage dispersion might increase after foreign acquisitions. Huttunen (2004) also examines average wages at the plant level in Finland. She finds a positive effect of foreign acquisition on wages which increases with the average schooling of the workers, implying increased wage dispersion from inflows of FDI.

This paper uses matched employer-employee data to examine whether foreign-owned firms differ from Swedish-owned firms in their wages to different types of workers. We contribute to the literature on FDI and wages in several respects. First, we use the individual worker's wage rather than firm or industry averages. Detailed matched employer-employee data, roughly covering 50 percent of the Swedish labor force, enables us to take into account individual- and firm heterogeneity when we estimate how ownership changes affect wage dispersion. Matching methods are used to control for possible endogeneity of foreign acquisitions.

Second, we can distinguish foreign acquisitions of domestic MNCs from acquisitions of local Swedish firms. We also analyze Swedish acquisitions of foreign- 
owned firms, which allow us to examine if ownership, firm type, or the acquisition itself affect wage dispersion.

Third, the often used categories "white collar vs. blue collar" and "production and non production workers" are highly heterogeneous within each class and constitute crude measures on skill levels. We use detailed information on education and job categories that is more closely related to skills. For example, among workers with high-skilled jobs, we are not only able to identify managers, but also the CEO and thereby, we can examine the impact of acquisitions on very specific groups of employees.

Our results suggest that foreign acquisitions of Swedish firms tend to have a positive impact on wages for high-skilled workers and a negative impact on wages for low-skilled workers, thus increasing wage dispersion. A more detailed breakdown of skill groups shows the positive impact of an acquisition to be concentrated to managers and the CEO in targeted firms, whereas other groups are either negatively affected or not affected at all by the change. As a consequence, the major part of the increased wage dispersion following acquisitions can be attributed to differences in the impact on wages between managers and CEOs on the one hand and the rest of the work force on the other. The positive influence on wages for high-skilled workers seems to be caused by the acquisition itself, rather than by the change of ownership, since ownership changes from foreign to Swedish also result in similar increases.

The paper is organized as follows. Section II discusses reasons for differences in the wage structure between different types of firms. Section III describes the data. Section IV contains the econometric methodology. Results are presented in Section V and the paper ends with some concluding remarks in Section VI. 


\section{Conceptual Framework}

FDI is likely to have an impact on wages, most obviously by increasing the demand for labor. FDI is also likely to have different effects on different types of workers. More precisely, multinational firms will locate production in a country partly due to the country's comparative advantage, thereby increasing demand for the abundant production factor which, in a country like Sweden, is likely to be skilled workers. ${ }^{2}$

Once more, this paper focuses on the effect of acquisitions on wages for different skill groups. The issue has not been elaborated to any considerable extent in the literature, but there is some theoretical work that might be used as a framework for our study.

First, the theory on the multinational firm, as expressed by for instance Dunning (1988), stresses the aspect of ownership advantages as a determinant of firms' competitiveness in foreign markets. Ownership advantage can be a brand name but it can also be specific technologies, distribution, and marketing systems. Since ownership advantages are important for the firm's competitiveness, it will try to guard them and restrict access to them by other competitors.

One way of restricting such access is by trying to reduce labor turnover. In other words, competitors can get access to, for instance, the firm's technologies by recruiting some of the firm's employees, and it is in the firm's interest to avoid such recruitment. The multinational firm might avoid the loss of employees by paying a wage premium. Presumably, the firm does not have to pay such a wage premium to all its employees, but only to those workers who might bring some of the firmspecific advantage with them if they join a competitor. It is plausible that such

\footnotetext{
${ }^{2}$ See e.g. Karpaty and Lundberg (2004).
} 
workers are mainly found among top-level employees and various specialists. Hence, we can expect increased wage dispersion when MNCs acquire non-MNCs.

Second, an acquisition can be an opportunity to renegotiate contracts and perform organizational changes (Schleifer and Summers, 1988; Bertrand and Mullainathan, 2003). Ownership changes are typically followed by a "shake out": a period of rationalizations. The management might require a wage premium to be willing to pursue such changes. Moreover, it is also likely that the new owners will depend on the management's knowledge of the firm and its network. However, there are no reasons to expect this mechanism to be specific for foreign acquisitions.

Finally, foreign-owned firms applying the wage structure used in foreign markets will lead to a difference in wages between foreign and domestic firms. Swedish wage differentials are small in an international comparison (see e.g. Blau and Kahn, 1996; Björklund et al., 1998). High-skilled workers, in particular, have comparably low wages in Sweden. It is possible that foreign-owned firms would find it difficult, or undesirable, to differentiate between similar employees in different countries. If this hypothesis were correct, we would expect foreign MNCs to raise wages for high-skilled workers in acquired Swedish firms.

As seen by the above discussion, the theoretical framework for analyzing the issue at hand is fragmented. It should also be noted that there are other theoretical papers where inflows of FDI can increase or decrease wage dispersion, depending on the assumptions made on, for instance, the initial equilibrium or the underlying parameter changes on trade costs and factor endowments (Markusen and Venables, 1998). The ambiguous theoretical results stress the importance of more empirical research to better understand the impact of FDI on wage dispersion. This paper contributes to this task. 


\section{Data and Descriptive Statistics}

The data used in this study comes from one individual-level based data set (LS) and one firm-level based dataset (FS) from Statistics Sweden. The data sets are linked by unique tracking numbers. The analysis covers the period 1996 to 2000 and uses firms with at least 20 employees in the entire private sector (manufacturing and non manufacturing). The individual wage statistics data set (LS) contains individual wage statistics based on Statistics Sweden's annual salary surveys and is supplemented by material from a series of official data registers. ${ }^{3}$ The dataset encompasses information on approximately 2 million observations per year (accounting for roughly $50 \%$ of the labor force) and includes information on workers' full-time equivalent wages, education, labor market experience, working hours, gender and occupation (job) codes

The firm-level data is obtained from financial statistics (FS). This data covers all Swedish firms with at least 20 employees and contains information on a large number of variables including capital stocks, sales, value added, firm size, investments, $R \& D$, ownership, and industry affiliation.

To separate out different types of firms, we divide our sample into three groups: foreign-owned MNCs, locally-owned MNCs, and locally-owned non-MNCs. A firm is a foreign-owned MNC if, according to information in the financial statistics, more than 50 percent of the equity is foreign owned. We define a locally-owned $\mathrm{MNC}$ as a firm reporting positive exports to other firms within the corporation.

\footnotetext{
${ }^{3}$ The sampling units of the survey consist of firms that are included in Statistics Sweden's firm data base (FS). A representative sample of firms is drawn from FS, stratified according to industry affiliation and firm size (number of employees). The sample size consists of between 8,000 and 11,000 firms for the period 1996-2000. The Central Confederation of Private Employers then provides employee information to Statistics Sweden on all its member firms that have (i) at least ten employees and (ii) are included in the sample. Firms with at least 500 employees are examined with probability one. The final sample includes information on around 50 percent of all employees within the entire private section.
} 
Finally, firms reporting no exports to other firms within the corporation are classified as locally-owned non-MNCs. ${ }^{4}$

- Table 1 about here -

Most firms are locally-owned non-MNCs, followed by foreign-owned MNCs and locally-owned MNCs. Our analysis focuses on acquisitions: firms changing ownership from foreign to local or from local to foreign. As seen in Table 1, the number of foreign acquisitions of domestically owned firms has increased from around 100 in 1997 to around 200 in 2000 . The number of acquisitions of foreignowned firms has also increased but remains relatively small.

In the analysis, we restrict our sample to those firms observed for at least four consecutive years. This means that for e.g. Swedish firms acquired by a foreign owner at period $(\mathrm{t})$, we only consider firms that are Swedish owned at $(\mathrm{t}-1)$ and remain foreign owned at year $(\mathrm{t}+1)$ and $(\mathrm{t}+2)$. The same restriction applies to individuals. As for their employing firms, we restrict individuals to remain in the same firm during the period of observation of the firm. This restriction enables us to control for both individual and firm-specific effects when analyzing the impact of foreign ownership on wages. It also means that we don't have to worry about the issue of endogenous job switchers, implying that part of an estimated foreign ownership effect can be caused by individuals switching firms through, for instance, promotions which, in turn, have a separate impact on wages. By restricting our sample to individuals who do not change employers, we directly focus on the effect

\footnotetext{
${ }^{4}$ Export information is available for firms with at least 50 employees or smaller firms with large sales. There might exist a few small multinationals that are classified as local firms, due to missing information on exports. The potential bias is likely to be slight, but it presumably means that the difference between MNCs and non-MNCs could be slightly larger than that presented in Section V.
} 
of the change in ownership. Descriptive statistics on our sub-sample of individuals and firms are presented in Table 2, together with figures on the share of each group of firms in total industry value added.

- Table 2 about here -

Local MNCs account for the largest share of value added, 39.5 percent, followed by local non-MNCs with 37.7 percent and foreign MNCs with 23.6 percent. Table 2 shows that foreign- and domestic-owned MNCs tend to be rather similar, and that domestic non-MNCs tend to differ from MNCs in some respects. More precisely, non-MNCs are relatively small in size, have a high proportion of female workers, and pay relatively low wages. Finally, domestically-owned MNCs tend to show higher profits per employee as compared to foreign-owned MNCs and locally-owned nonMNCs.

Table 2 also shows higher wages in MNCs than in local firms. This is true for both domestic and foreign MNCs. The average wage for employees in domesticowned and foreign-owned MNCs is around 21,500 SEK and around 19,700 SEK for workers in local firms. Finally, non-MNCs employ a relatively high share of females and also have older and more experienced workers.

It is important for our analysis that we adequately distinguish between workers with different skills. The most common way of doing this in the literature is to use blue- and white-collar workers, or production and non-production workers. This is a crude distinction. For instance, white-collar workers include the manager, but also the person emptying his dustbin; blue-collar workers include the truck driver, but also the specialist installing and running various types of high-tech machinery. 
We use two different criteria to separate between high- and low-skilled workers to avoid drawing conclusions based on results caused by poor and crude distinctions. The data categorizes each worker to one of 105 different job-types based on the international standard classification of occupations (ISCO-88), and we aggregate these job-types to three broader categories. More precisely, managers and specialists are considered as high-skilled, workers engaged in various service functions and sales are considered as medium-skilled, and the rest are characterized as low-skilled. According to this definition, high-skilled workers constitute 17 percent of the total workforce, medium-skilled workers about 44 and low-skilled about 37 percent. As expected, high-skilled workers have the highest salaries followed by medium-skilled and low-skilled (see the upper part of Table 2).

The workers' educational background is an alternative measure on skill. More precisely, we have divided workers into three groups: workers with tertiary education, secondary education, or not more than primary education. The use of education makes the high-skilled group and low-skilled group smaller as compared to the distinction according to job-types. The shares of high-, medium-, and low-skilled according to education are 9, 65 and 23 percent, respectively. Wages remain relatively high for high-skilled workers and low for low-skilled workers (Table 2).

Table 2 also compares wages between skill groups for different types of firms. The average wage is lowest in Swedish non-MNCs for all skill groups and these firms also exhibit the lowest wage dispersion.

The imposed restrictions on firm survival and workers remaining in the same firm may lead to a sample selection bias. Therefore, we calculated the sample statistics without any restrictions. Our restrictions seem to have a very small impact on our calculations. For example, the average wage for workers in local Swedish 
firms, Swedish MNCs, and foreign-owned firms changes from SEK 19 693, 21 595, and 21364 to 18966,21 197, and 20570 respectively. The effect on the labor force composition is even smaller, but the restrictions leave us with slightly larger and more capital intensive firms. ${ }^{5}$

As highlighted by Shleifer and Summers (1989) and Bertrand and Mullainathan (2003), acquisitions may trigger a reconstruction of the firm. In Table 3, we present some descriptive statistics on the "shakeout effect" following an acquisition. A number of interesting conclusions can be drawn. For instance, acquired firms tend to shrink in size as compared to non-acquired firms. This downsizing may be caused by a centralization of administrative units to the parent firm. The composition of different skill groups remains almost unaffected two years after an acquisition, but wages seem to be declining. Hence, the difference in skill compositions between MNCs and non-MNCs (Table 2) seems to be a selection effect rather than being caused by a transformation of acquired firms.

As we have detailed information on individuals' jobs, we are able to trace the wage development for very specific groups of employees, such as the CEOs. The survival ratio of CEOs in acquired firms is 58 percent after one year and 37 percent after two years (not shown). This can be compared with the survival rate for CEOs in firms that are not acquired by foreign owners, which is 71 and 55 percent respectively. Hence, CEOs tend to be relatively footloose and an acquisition increases the likelihood that the CEO will leave the firm.

- Table 3 about here -

\footnotetext{
${ }^{5}$ Unrestricted sample statistics are available upon request.
} 
The final row in Table 3 shows that of those CEOs that stay with the firm after a foreign acquisition, roughly 30 percent are moved into another position (within the firm) two years after the acquisition.

\section{Econometric Methodology}

Our analysis will be based on the following augmented Mincer equation:

$$
\ln w_{i j t}=\beta_{0}+\sum_{S} \beta_{1 S} \mathrm{~S}_{i j t}+\sum_{S} \beta_{2 S} \mathrm{O}{ }_{j t} \mathrm{~S}_{i j t}+\mathrm{X}_{i j t}^{\prime} \beta_{2}+\mathrm{F}_{j t}^{\prime} \beta_{3}+\alpha_{i}+\eta_{j}+\lambda_{t}+\varepsilon_{i j t}
$$

where $w_{i t}$ is the full-time equivalent monthly wage for worker $i$ in firm $j$ at time $t$; $O$ is a foreign ownership dummy for firm $j$, the foreign ownership dummy is 1 if at least 50 percent of the equity is foreign owned, and zero otherwise; $S$ is the skill level of worker $i$ defined according to job type or educational level, $O_{j t} * S_{i j \mathrm{t}}$ is an interaction between ownership and skill, capturing the wage premium for different skill groups working in a certain firm type, $X$ is a vector of individual characteristics including gender and labor market experience, $F$ contains firm-level variables such as $(\log )$ firm size, profits per employee, capital intensity, and industry affiliation. Finally, $\alpha_{i}, \lambda_{t}$, and $\eta_{\mathrm{j}}$ are fixed individual-, time- and firm-effects, respectively, and $\varepsilon_{\mathrm{ijt}}$ is the classical error term.

Foreign-owned firms may, in some unobserved characteristics, differ from domestically owned firms which, in turn, might explain wage differences. One way of controlling for this bias is by examining firms that change ownership. In other words, we would not expect any change in wages following an acquisition, if it is unobserved firm- or individual characteristics, rather than ownership itself that explain the wages. Therefore, we restrict the analysis to firms changing ownership from domestic to foreign or from foreign to domestic. 
To isolate the impact of multinational status, we also analyze foreign acquisitions of both Swedish MNCs and local Swedish firms.

\section{Propensity score matching and difference-in-difference}

One problem with estimating the causal effect of an acquisition on wages concerns the endogeneity of firms being acquired. In other words, it is not likely to be random which firms are acquired and acquired firms might exhibit characteristics systematically differing from the characteristics of other firms. Moreover, and analogously to the problem in the evaluation literature of non-random treatment groups, the characteristics of the firms that become foreign owned might be such that they would in any case develop differently than their non-acquired counterparts. This means that estimates on outcome variables (such as wages) become biased.

We approach this problem by way of propensity score matching combined with the more general difference-in-differences $(\mathrm{d}-\mathrm{i}-\mathrm{d})$ technique. Let $\mathrm{A} \in\{\mathrm{T}, \mathrm{C}\}$ be an acquisition indicator equal to $\mathrm{T}$ for firms being acquired (the treatment group) and equal to $\mathrm{C}$ for firms that do not change ownership status (the control group). $w_{i, t+s}^{T}$ denote the wage at time $\mathrm{t}+\mathrm{s}$ for a firm $i$ that has been acquired at time $\mathrm{t}$, and $w_{i, t+s}^{C}$ is the wage that would have been observed if the firm had not been acquired. Obviously, no firm can be observed in two different states at the same time, so either $w_{i, t+s}^{T}$ or $w_{i, t+s}^{C}$ is missing for each firm $i$. This fundamental problem of causal inference is sometimes described as the evaluation problem of missing data. However, under certain assumptions, the expected average treatment effect for the population of firms can instead be identified. This effect is equal to $E\left\{w_{t+s}^{T}-w_{t+s}^{C} \mid A=T\right\}=E\left\{w_{t+s}^{T} \mid A=T\right\}-E\left\{w_{t+s}^{C} \mid A=T\right\}$. Matching techniques can 
be used to construct a sample of non-acquired twins to the acquired firms and, thus, approximate the non-observed counterfactual event in the last term. The differencein-difference approach compares wage changes for the treated group of acquired firms with some relevant control group of firms that are not acquired. This amounts to estimating $\beta=\left(w_{t_{1}}^{T}-w_{t_{0}}^{T}\right)-\left(w_{t_{1}}^{C}-w_{t_{0}}^{C}\right)$, where $\beta$ is the unknown $\mathrm{d}-\mathrm{i}$-d parameter and $t_{0}$ and $t_{1}$ are the time periods before and after an acquisition.

The matching procedure in this paper uses the algorithms provided by Becker and Ichino (2002) and Leuven and Sianesi (2003). The propensity score is estimated with the Nearest-Neighbor method, without replacements. ${ }^{6}$ The balancing property of the propensity score is tested and satisfied in all estimations. ${ }^{7}$ Since we have a panel of firms and individuals observed over time, the matching of firms is calculated yearby-year using lagged covariates. Having obtained a control group of firms, we then proceed to estimate the impact of acquisitions on individual wages by means of combining propensity score matching with the difference-in-difference estimator, as suggested by Blundell and Costa Dias (2000). This means that we can examine the dynamic effects of takeovers on wages.

The $\mathrm{d}$-i-d estimator will be estimated from the following individual wage equation:

$$
\ln w_{i j t}=\sum_{s} \beta_{1 s} A f t e r_{i j t}+\delta T_{i j}+\eta_{t}+\varepsilon_{i j t}
$$

where After $_{i j t}$ is a dummy variable that is equal to one for the periods after the employing firm has been acquired, and zero otherwise. $T$ is a fixed acquisition

\footnotetext{
${ }^{6}$ See Heyman et al. (2004) for more details on the matching.

${ }^{7}$ We use observations in the region of common support only.
} 
(group) effect that that is equal to one if the firm belongs to the treatment group, and zero otherwise. This dummy variable captures level differences between acquired and non-acquired firms before the acquisition. The time effect $\eta_{t}$ captures aggregate period effects that are common between the two groups. The estimated d-i-d effect of an acquisition for different skill-groups is given by the $\beta$ 's. All estimated regressions include the same set of individual, firm and industry controls as in equation (1).

\section{Results}

Table 4 shows wages for individuals working in firms changing ownership from domestic to foreign.

- Table 4 about here -

High-skill workers benefit from foreign acquisitions. The wage premium is small, however; around one percent, irrespective if education or job-types are used as the skill indicator. Moreover, the wage premium is larger after acquisitions of Swedish MNCs than after acquisitions of Swedish local firms, suggesting that there might be a different mechanism than internalization which explains the wage premium after an acquisition.

Wages for medium-skilled and low-skilled workers decrease substantially after a foreign-acquisition: by around six and four percent, respectively, in estimations with education, and by around three and six percent, respectively, in estimations with job-types. The negative effect on wages is larger after foreign acquisitions of Swedish MNCs than after acquisitions of local Swedish firms. Hence, 
our results suggest increased wage dispersion following an acquisition, independent of what type of firm is acquired.

The above estimations on foreign takeovers are biased if foreigners are targeting firms that also exhibit certain specific characteristics affecting wages. Therefore, we use a matched sample of non-targeted firms in estimations 9-12. The results remain relatively stable using the matched sample; foreign acquisitions lead to increased high-skill wages and decreased medium- and low-skill wages. However, the coefficients change and the positive effect on high-skill wages increases from roughly 1.5 percent to 4.2-5.2 percent. On the other hand, the negative effect on medium- and low-skilled wages is lower than in the unmatched sample. Hence, the matching seems to shift the distribution of wage effects to the right.

As a robustness test, we re-estimated models 1 through 6 in Table 4, relaxing the imposed restrictions on firms and workers. The number of observations then increased from roughly 1.2 million to 4.2 million. Relaxing the restrictions only had a minor effect and did not upset the result of increased wage dispersion following an acquisition. For instance, the wage premium for workers with tertiary-, secondary-, and primary education changed from $0.015,-0.038$, and -0.059 to $0.054,-0.012$, and 0.030, respectively. Using job types, high-, medium- and low skilled jobs, the wage premium changed from $0.015,-0.057$, and -0.033 to $0.043,-0.016$, and -0.023 . Hence, relaxing the restrictions affects the point estimates but leaves the overall picture unchanged. $^{8}$

An alternative way of capturing the impact of an acquisition, reflecting the dynamic pattern, is to use difference-in-difference (d-i-d) estimations. Results from combining matching techniques and $\mathrm{d}-\mathrm{i}-\mathrm{d}$ are presented in Table 5.

\footnotetext{
${ }^{8}$ Estimations on the full unrestricted sample are available upon request.
} 
- Table 5 about here -

As seen in Table 5, the positive wage effect for highly educated workers and the negative effect for low- and medium educated workers remain. The results are less clear when we use job types, but still indicate increasing wage dispersion by a comparably large wage decline for low-skilled jobs.

If the increased wage dispersion after a foreign acquisition is caused by the ownership change itself, rather than the change from domestic to foreign control, we would expect to see similar patterns also after other types of ownership changes. This possibility is examined in Table 6 where domestic acquisitions of foreign firms are studied.

- Table 6 about here -

The results in Table 6 show a wage increase for high-skilled workers after an ownership change from foreign to Swedish. The magnitudes are slightly larger than for the corresponding changes from Swedish to foreign. ${ }^{9}$ However, domestic acquisitions of foreign-owned firms do not depress wages for medium- and lowskilled workers. Hence, ownership changes in themselves have a general positive effect on high-skilled workers' wages, thereby increasing wage dispersion irrespective of whether the acquired firm is an $\mathrm{MNC}$, or whether the change is from foreign- to domestic ownership or from domestic- to foreign ownership.

\footnotetext{
${ }^{9}$ See Tables 4 and 6.
} 
One possible explanation as to why the benefits of an acquisition are concentrated to skilled workers could be a strategy by new owners to keep key personnel in the company. Such personnel may possess important knowledge and networks which are essential for the new owners to keep in the firm. Moreover, Shleifer and Summers (1988) argue that takeovers are often followed by a renegotiation of labor contracts and the abolishment of extra-marginal wages. It is possible, though, that the new owners must pay a wage premium to key personnel in the firm to make them willing to pursue such deteriorations of other employees' contracts and, at the same time, keep the network of the firm intact. However, highskill is a broad concept and our categories include a large number of different jobtypes. It is not obvious that all workers classified as "skilled workers" need to be compensated. To examine this issue, we disaggregate the high-skill group and specifically look at the effect on wages of, first, all managers (estimations $1-3 ; 7$ ) and second, on the wages of CEOs (estimations 4-6; 8). These results are shown in Table 7.

- Table 7 about here -

It is strikingly clear that the higher up in the job-hierarchy, the higher is the wage premium from a change in ownership. Starting with foreign takeovers, these managers increase their wages, compared to managers that remain working in a Swedish firm, by between 1 and 3 percent. The effect is even higher for CEOs: around 5 percent. Moreover, separating out managers has a negative effect on the remaining group of high-skill employees with no remaining wage premium. Hence, the only group of workers that (in terms of wages) benefits from an acquisition is 
managers in general and the CEO in particular. Hence, results suggest that only key persons benefit from an acquisition.

Analyzing takeovers of foreign firms confirms earlier findings: a positive effect on wages for managers and CEOs that is of similar size as those found for foreign takeovers and, after removing managers from the group of skilled employees, a decreased coefficient for the remaining group of skilled workers. ${ }^{10}$ Hence, the results might suggest that to successfully carry out an acquisition, the acquiring firm favors key personnel, while the position of other groups is weakened.

\section{Concluding Remarks}

Global integration presumably affects relative wages. Whereas the issue of trade and wages has received substantial attention in the literature, less is known about how inflow of FDI affects relative wages. This is unfortunate, considering the important and growing role of FDI in the global economy. In this paper, we have analyzed the impact of acquisitions on wages and wage dispersion in Sweden. To achieve this task, we divided workers into different skill groups according to job types and educational background.

It is clear from our analysis that acquisitions affect relative wages. The wage benefit of acquisitions is strongly concentrated to managers in general and to the CEO in particular.

Out of CEOs that remain in the firm after an acquisition, two thirds are still CEOs two years after the firm was acquired. These CEOs increase their salary by around five percent as compared to CEOs in firms that are not acquired.

\footnotetext{
${ }^{10}$ The estimations on foreign takeovers were also made on the matched sample of firms (not shown) and the results are only slightly larger coefficient values than those reported for the unmatched sample in Table 9.
} 
The wage premium to other managers is also positive, but smaller in size. Wages for other high-skilled workers are not considerably affected by an acquisition, but wages for medium- and low-skilled workers decline when foreign owners acquire Swedish firms. More specifically, foreign acquisitions decrease wages by around six percent for medium-skilled workers and by around three to four percent for lowskilled workers.

It is worth emphasizing that it does not seem to be internationalization that is affecting wages. Foreign acquisitions of Swedish MNCs that are already internationalized have roughly the same effect as foreign acquisitions of Swedish local firms.

Accordingly, the positive wage effect for managers and CEOs seems to be caused by the acquisition itself, and not by the kind of ownership. Foreign acquisitions of Swedish-owned firms and domestic acquisitions of foreign-owned firms result in very similar increases in wages for management and CEOs. One plausible explanation is that the new owners pay a wage premium to the management to, first, persuade these individuals to remain in the company, thereby ensuring that the knowledge about the firm and its network is intact and, second, to ensure that they participate in the shakeout that might follow after an acquisition.

The conclusion from our paper is that FDI increases wage dispersion: the inflow of FDI to Sweden between 1996 and 2000 only had a positive effect on wages for CEOs and management. The reason for this development is uncertain, but seems to be more related to the acquisitions themselves than to increased internationalization.

Our results lead to new questions. An obvious one is how to develop the theory of acquisitions and how contracts are negotiated during an acquisition. 
Another question is how the results compare to purely domestic acquisitions. Unfortunately, we cannot examine such takeovers with our data. There are, however, a few studies on domestic acquisitions and wages. ${ }^{11}$ The evidence from these studies are mixed. Though our results are not perfectly comparable with pure domestic acquisitions, the mixed results might be driven by the same asymmetric impact of acquisitions on high- and low skilled workers that we find in our study.

\section{References}

Baldwin, R.E. (1994), "The Effect of Trade and Foreign Direct Investment on Employment and Relative Wages", OECD Economic Studies, No.23, pp. 7-54.

Becker, Sascha and Andrea Ichino (2002), "Estimation of average treatment effects based on propensity score", The Stata Journal, Vol. 2, No. 4, pp. 358-377.

Bertrand, M., and Mullainathan, S., (2003), "Enjoying the Quiet Life? Corporate Governance and Managerial Control", Journal of Political Economy, 111(51), 10431076.

Blau, F. and Kahn, L., (1996) "International Differences in Male Wage Inequality: Institutions versus Market Forces”, Journal of Political Economy, 104, 791-837.

Björklund, A., Palme, M., and Svensson, M., (1998), "Income Distribution in Sweden: An Assessment Using Different Income Concepts". Swedish Economic Policy Review, Vol 2(2), 229-266.

Blonigen, B.A. and M.J. Slaughter (1999), "Foreign-Affiliate Activity and US Skill Upgrading”, The Review of Economics and Statistics, Volume 83, No.2, pp. 362-376.

Blundell, Richard and Costa Dias, Monica (2000), "Evaluation Methods for nonexperimental data", Fiscal Studies, vol. 21, no. 4, pp. 427-468.

Conyon, M.J., S. Girma, S. Thompson, and P.W. Wright (2004), "Do Wages Rise of Fall Following Merger?", Oxford Bulletin of Economics and Statistics, Vol. 65, pp. 847-862.

Dunning, J.H., (1988), Multinationals, Technology and Competitiveness. Allen \& Unwin, London.

\footnotetext{
${ }^{11}$ See e.g. Conyon et al. (2004), and the references therein, for evidence on the relationship between acquisitions and wages.
} 
Girma, S. and H. Görg (2003), "Evaluating the Causal Effects of Foreign Acquisition on Domestic Skilled and Unskilled Wages", Working Paper No. 2003/40, Leverhulme Centre for Research on Globalisation and Economic Policy, Nottingham University.

Görg, Holger and David Greenaway (2004), "Much Ado About Nothing? Do Domestic Firms Really Benefit from Foreign Direct Investment?", World Bank Research Observer, Vol. 19, No. 2, pp.171-97.

Heyman, F., Sjöholm, F., and P. Tingvall (2004), "Is There Really a Foreign Ownership Wage Premium? Evidence from Matched Employer-Employee Data", Stockholm School of Economics, EIJS Working Paper No. 206.

Huttunen, K. (2004), "The Effect of Foreign Acquisition on Wages and Skill Composition", Mimeo, University of Helsinki.

Karpaty, P., and Lundberg, L (2004), Foreign Direct Investment and Productivity Spillovers in Swedish Manufacturing, Trade Union Institute for Economic Research (FIEF) Working paper No. 194, Sweden.

Leuven, Edward and Barbara Sianesi (2003), "PSMATCH2: Stata module to perform full Mahalanobis and propensity score matching, common support graphing, and covariate imbalance testing", http://ideas.repec.org/c/boc/bocode/s432001.html. Version 1.2.3.

Lipsey, Robert E. (2004), "Home- and Host-Country Effects of Foreign Direct Investment," in Robert E. Baldwin and L. Alan Winters (Eds), Challenges to globalization, Chicago, University of Chicago Press.

Markusen, J.K. (2004), Multinational Firms and the Theory of International Trade, Cambridge MA: MIT Press.

Markusen, J.K. and Venables, A. (1998), "Multinational Firms and the New Trade Theory", Journal of International Economics, Vol. 43, pp.183-204.

Shleifer, A., and Summers, L.H., (1988), "Breach of Trust in Hostile Takeovers", In Auerbach, A.J. (ed.), Corporate Takeovers: Causes and Consequences, Chicago: University of Chicago Press.

Taylor, K. and N. Driffield (2005), "Wage Dispersion and the Role of Multinationals: Evidence from UK Panel Data", Labour Economics, Vol. 12, pp. 223-249. 


\section{TABLES}

Table 1. Number of firms and acquisitions by ownership in Sweden 1996-2000.

\begin{tabular}{llllll}
\hline & $\mathbf{1 9 9 6}$ & $\mathbf{1 9 9 7}$ & $\mathbf{1 9 9 8}$ & \multicolumn{1}{c}{$\mathbf{1 9 9 9}$} & \multicolumn{1}{c}{$\mathbf{2 0 0 0}$} \\
\hline Swedish Locally-owned non-MNCs & 8981 & 9300 & 10254 & 10274 & 10737 \\
Swedish MNCs & 621 & 1,087 & 939 & 800 & 859 \\
Foreign MNCs & 1360 & 1460 & 1594 & 1725 & 1885 \\
Foreign acquisitions of locally owned firms & --- & 118 & 162 & 194 & 207 \\
Domestic acquisitions of foreign-owned MNCs & --- & 57 & 45 & 44 & 76 \\
\hline
\end{tabular}

Note: Figures in the table are based on data on all firms with at least 20 employees in the

Finance Statistics data set (FS).

Table 2. Descriptive statistics of firms with different ownership (1996-2000).

\begin{tabular}{|c|c|c|c|c|c|c|}
\hline & \multicolumn{2}{|c|}{$\begin{array}{c}\text { Domestic-owned } \\
\text { non-MNCs }\end{array}$} & \multicolumn{2}{|c|}{$\begin{array}{c}\text { Domestic-owned } \\
\text { MNCs }\end{array}$} & \multicolumn{2}{|c|}{$\begin{array}{c}\text { Foreign-owned } \\
\text { MNCs }\end{array}$} \\
\hline \multicolumn{7}{|c|}{ Individual statistics 1996-2000. Stdv. within parenthesis (.) } \\
\hline Monthly average wage & 19693 & $(7094)$ & 21595 & $(8400)$ & 21364 & $(8732)$ \\
\hline Wage high-skill jobs & 27555 & & 31284 & & 31045 & \\
\hline Wage medium-skill jobs & 19026 & & 20228 & & 19859 & \\
\hline Wage low-skill jobs & 16847 & & 18287 & & 17154 & \\
\hline Wage high education & 28751 & & 32814 & & 32917 & \\
\hline Wage medium education & 19335 & & 20667 & & 20762 & \\
\hline Wage low education & 17479 & & 18619 & & 18209 & \\
\hline Share female & 0.42 & $(0.49)$ & 0.27 & $(0.44)$ & 0.30 & $(0.46)$ \\
\hline Share of high-educated & 0.082 & $(0.27)$ & 0.11 & $(0.31)$ & 0.10 & $(0.30)$ \\
\hline Share of med-educated & 0.69 & $(0.46)$ & 0.67 & $(0.47)$ & 0.63 & $(0.48)$ \\
\hline Share of low-educated & 0.22 & $(0.42)$ & 0.22 & $(0.41)$ & 0.26 & $(0.44)$ \\
\hline Share of high-job & 0.17 & $(0.38)$ & 0.17 & $(0.37)$ & 0.19 & $(0.40)$ \\
\hline Share of med-job & 0.47 & $(0.50)$ & 0.57 & $(0.49)$ & 0.57 & $(0.49)$ \\
\hline Share of low-job & 0.35 & $(0.48)$ & 0.26 & $(0.44)$ & 0.23 & $(0.42)$ \\
\hline Experience & 26.1 & (10.9) & 23.6 & $(11.2)$ & 24.9 & $(11.2)$ \\
\hline Age of employees & 44 & $(10.2)$ & 42 & $(10.6)$ & 43 & $(10.4)$ \\
\hline No of obs. & 774757 & & 547375 & & 298068 & \\
\hline \multicolumn{7}{|c|}{ Firm statistics 1996-2000 Stdv. within parenthesis (.) } \\
\hline Firm size & 375 & $(1583)$ & 947 & $(2379)$ & 574 & $(776)$ \\
\hline log Capital intensity & 0.63 & $(1.88)$ & 0.67 & $(1.11)$ & 0.60 & $(1.34)$ \\
\hline Profit per employee & 1.18 & $(13.9)$ & 1.95 & $(15.3)$ & 1.08 & $(317)$ \\
\hline Sales per employee & 19.6 & $(37.4)$ & 20.76 & $(31.2)$ & 26.2 & $(47.8)$ \\
\hline No of obs. & 3522 & & 1026 & & 1007 & \\
\hline Share of tot value added & 37.7 & & 39.5 & & 23.6 & \\
\hline
\end{tabular}

Note: Figures are based on the sub-sample of firms and workers in the employer-employee linked data. See Section III for details. 
Table 3. Acquisition shakeout: ratios, acquired to non-acquired firms.

\begin{tabular}{llrrr}
\hline & $\mathrm{t}-1$ & $\mathrm{t}$ & $\mathrm{t}+1$ & $\mathrm{t}+2$ \\
\hline Size & 1.161 & 1.104 & 1.068 & 1.055 \\
Share high educated & 1.005 & 0.953 & 0.974 & 1.015 \\
Share medium educated & 1.005 & 1.017 & 1.008 & 1.004 \\
Share low educated & 0.987 & 1.001 & 1.002 & 0.981 \\
Salary high educated & 1.221 & 1.160 & 1.185 & 1.154 \\
Salary medium educated & 1.067 & 1.073 & 1.074 & 1.062 \\
Salary low educated & 1.076 & 1.038 & 1.028 & 1.054 \\
Percent of CEOs remaining in the firm as CEOs, & & & & \\
conditional on presence in t-1 and staying in the & 100 & 88 & & \\
firm until at least $\mathrm{t}+2$. & & & & \\
\hline
\end{tabular}

Note: Figures correspond to foreign acquisitions of domestic firms. 


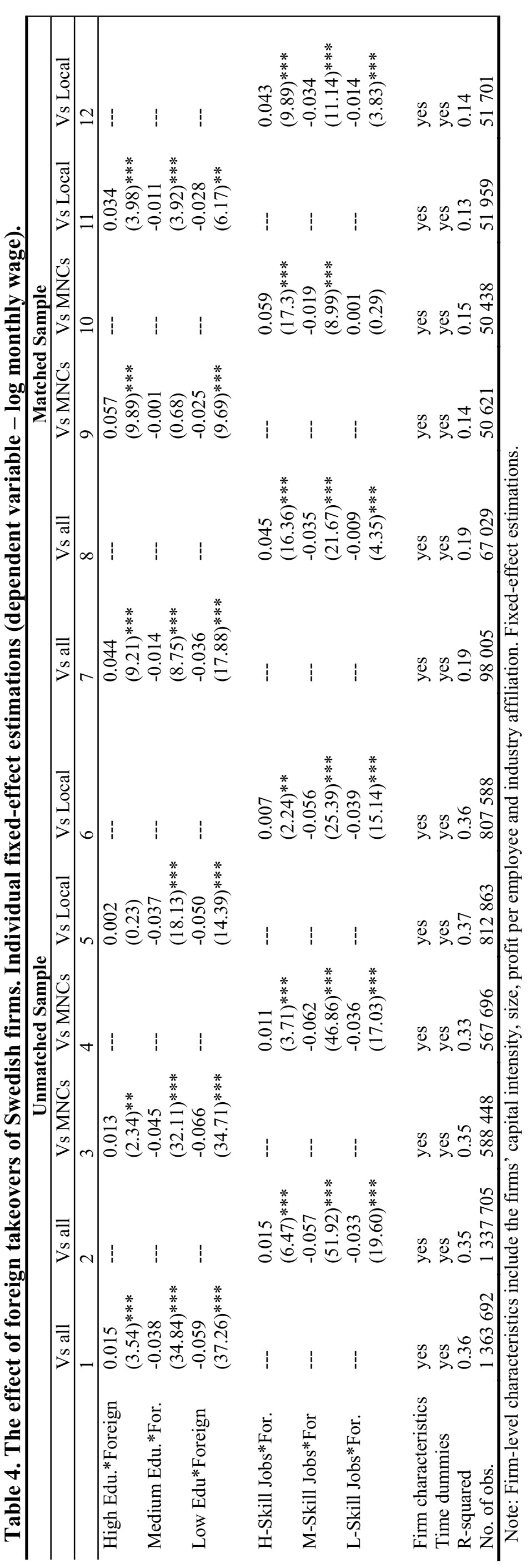


Table 5. Difference-in-difference estimations. Foreign takeover of Swedish firms (dependent variable - log monthly wage).

\begin{tabular}{|c|c|c|c|c|}
\hline & \multicolumn{2}{|c|}{ Wage growth $(t+1)-(t-1)$} & \multicolumn{2}{|c|}{ Wage growth $(\mathrm{t}+2)-(\mathrm{t}-1)$} \\
\hline & Job type & Edu. category & Job type & Edu. category \\
\hline High edu & & $\begin{array}{l}0.360 \\
(53.79)^{* * *}\end{array}$ & & $\begin{array}{l}0.382 \\
(57.03)^{* * *}\end{array}$ \\
\hline Medium edu & & $\begin{array}{l}0.069 \\
(18.88) * * *\end{array}$ & & $\begin{array}{l}0.075 \\
(20.79) * * *\end{array}$ \\
\hline High Edu * After & & $\begin{array}{l}0.052 \\
(3.29) * * *\end{array}$ & & $\begin{array}{l}0.031 \\
(1.93)^{* *}\end{array}$ \\
\hline Med Edu. * After & & $\begin{array}{l}-0.027 \\
(-4.61) * * *\end{array}$ & & $\begin{array}{l}-0.079 \\
(-13.79) * * *\end{array}$ \\
\hline Low Edu * After & & $\begin{array}{l}-0.027 \\
(-4.31)^{* * *}\end{array}$ & & $\begin{array}{l}-0.080 \\
(-13.41)^{* * *}\end{array}$ \\
\hline High job & $\begin{array}{l}0.385 \\
(77.11)^{* * *}\end{array}$ & & $\begin{array}{l}0.400 \\
(79.48) * * *\end{array}$ & \\
\hline Medium job & $\begin{array}{l}0.099 \\
(30.71) * * *\end{array}$ & & $\begin{array}{l}0.103 \\
(32.19) * * *\end{array}$ & \\
\hline H-Skill Job * After & $\begin{array}{l}-0.017 \\
(-1.82)^{*}\end{array}$ & & $\begin{array}{l}-0.052 \\
(-5.41)^{* * *}\end{array}$ & \\
\hline M-Skill Job * After & $\begin{array}{l}-0.009 \\
(-1.70)^{*}\end{array}$ & & $\begin{array}{l}-0.088 \\
(-16.68)^{* * *}\end{array}$ & \\
\hline L-Skill Job * After & $\begin{array}{l}-0.058 \\
(-9.61)^{* * *}\end{array}$ & & $\begin{array}{l}-0.067 \\
(-11.43)^{* * *}\end{array}$ & \\
\hline Treated & $\begin{array}{l}0.028 \\
(5.72)^{* * *}\end{array}$ & $\begin{array}{l}-0.008 \\
(-1.54)\end{array}$ & $\begin{array}{l}0.022 \\
(4.53)^{* * *}\end{array}$ & $\begin{array}{l}-0.007 \\
(-1.24)\end{array}$ \\
\hline Period & $\begin{array}{l}0.079 \\
(17.99) * * *\end{array}$ & $\begin{array}{l}0.079 \\
(17.04)^{* * * *}\end{array}$ & $\begin{array}{l}0.122 \\
(27.52) * * *\end{array}$ & $\begin{array}{l}0.119 \\
(25.63) * * *\end{array}$ \\
\hline Firm characteristics & yes & yes & yes & yes \\
\hline Time dummies & yes & yes & yes & yes \\
\hline R-squared & 0.44 & 0.35 & 0.43 & 0.34 \\
\hline No. of obs. & 33537 & 33720 & 33394 & 33704 \\
\hline
\end{tabular}

Note: Firm-level characteristics include the firms' capital intensity, size, profit per employee,

share of females and industry affiliation.

Table 6. Domestic takeovers of foreign-owned firms. Individual fixed-effect estimations (dependent variable - log monthly wage).

\begin{tabular}{lllll}
\hline & 1 & 2 & 3 & 4 \\
\hline High Education* Foreign & 0.024 & 0.022 & --- & --- \\
& $(3.48)^{* * *}$ & $(3.19)^{* * *}$ & & \\
Medium Education * Foreign & -0.000 & 0.001 & --- & --- \\
& $(-0.12)$ & $(0.29)$ & & \\
Low Education*Foreign & -0.003 & -0.000 & --- & --- \\
& $(-0.44)$ & $(-0.07)$ & & \\
High-Skill Jobs*Foreign & -- & -- & 0.016 & 0.016 \\
& & & $(3.28)^{* * *}$ & $(3.33)^{* * *}$ \\
Medium-Skill Jobs*Foreign & --- & --- & 0.002 & 0.003 \\
& & & $(0.78)$ & $(1.12)$ \\
Low-Skill Jobs*Foreign & --- & --- & -0.013 & -0.009 \\
& & & $(-1.94)^{*}$ & $(-1.40)$ \\
Firm characteristics & no & yes & no & yes \\
Time dummies & yes & yes & yes & yes \\
R-squared & 0.34 & 0.34 & 0.34 & 0.34 \\
No. of observations & 303761 & 303681 & 296408 & 296328 \\
\hline Note: Firm-
\end{tabular}

Note: Firm-level characteristics include the firms' capital intensity, size, profit per employee and industry affiliation. Fixed-effect estimations. 


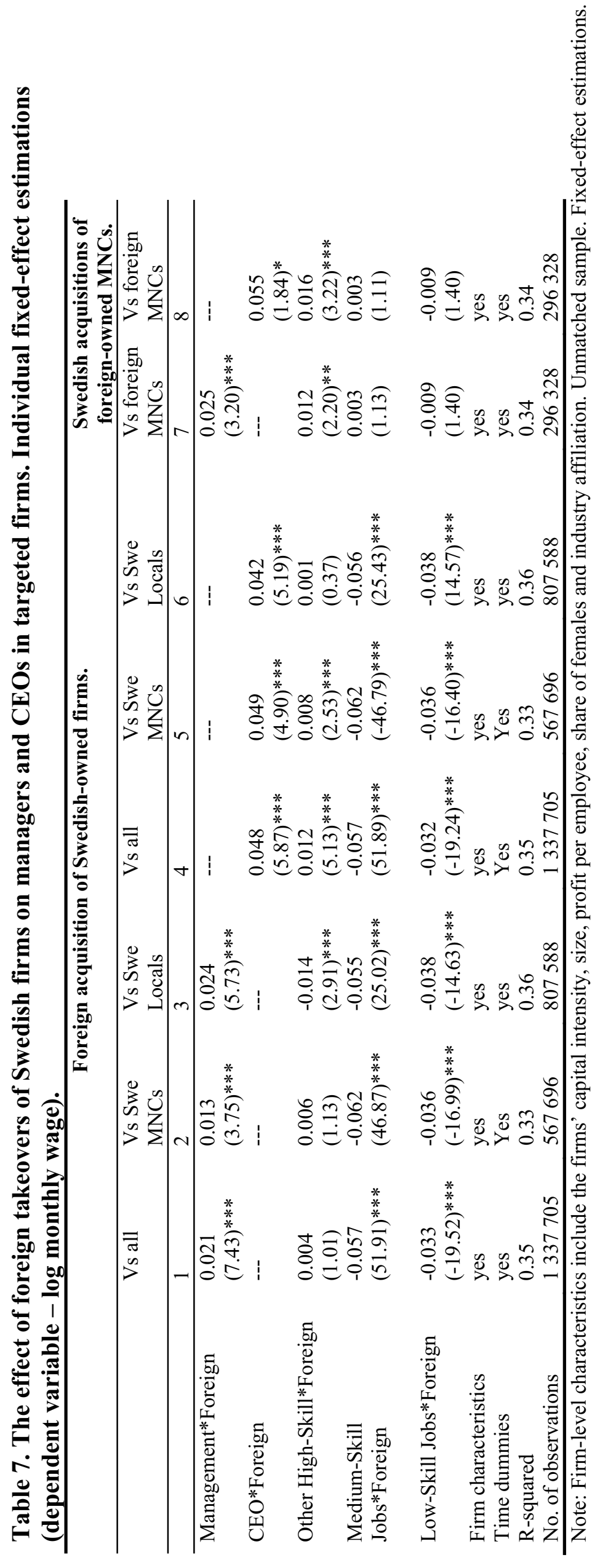




\section{Appendix}

Table A1. Variable definitions.

\section{Firm variables}

Profits per employee

Capital Intensity

Labor productivity

Foreign ownership

Size

Female-share
Profits, net of financial deduction, 1990 year prices, divided by number of employees.

Capital stock per employee, 1990-year prices. Value added per employee, 1990 year prices.

Dummy $=1$ if more than 50 percent of a firm's votes are foreign owned.

Number of employees.

Share of female employees.
FS

FS

FS

FS

FS

RAMS

\section{Individual variables}

Wage

Full time equivalent monthly wage per employee, 1990 -year prices. Statistics Sweden has calculated these for both blue-collar and white collar workers.

Female Dummy $=1$ if female, $=0$ if male.

Dummy $=1$ if blue-collar worker, $=0$ if white-collar worker.

Education dummies

Based on the Swedish education nomenclature

LS (SUN-codes).

(1). Elementary school $<9$ years

(2). Compulsory school $=9$ years

(3). Upper secondary, 2 years

(4). Upper secondary, 3 years

(5). Upper secondary, 4 years

(6). Undergraduate studies, 3 years

(7). $\mathrm{PhD}$.

Experience

Age minus number of years of schooling minus seven.

Note: Abbreviations: Financial Statistics (FS) and Individual Wage Statistics (LS). 